\title{
Development of Interactive E-Module Based on Human Digestive System Material Inquiry on Theme 3 About Healthy Foods for Fifth Grade Elementary School
}

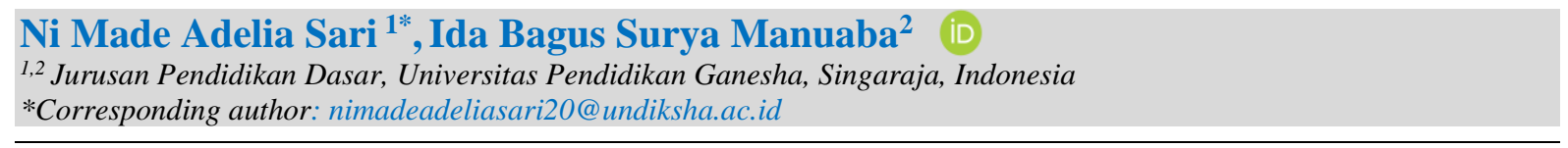

\section{Abstrak}

Saat ini bahan ajar dan media pembelajaran konvensional belum dapat memenuhi tuntutan pembelajaran yang ada di era evolusi 4.0. Hal ini mengakibatkan banyak siswa yang tidak memahami materi pelajaran sehingga tujuan pembelajaran belum tercapai secara maksimal. Penelitian ini bertujuan untuk menghasilkan modul elektronik interaktif berbasis inkuiri penunjang pembelajaran. Jenis penelitian ini adalah penelitian pengembangan dengan menggunakan model ADDIE yang meliputi tahap analisis, perancangan, pengembangan, implementasi, dan tahap evaluasi. Teknik yang digunakan dalam mengumpulkan data adalah observasi, wawancara, dan kuesioner. Instrument yang digunakan dapat mengumpulkan data adalah kuesioner. Analisis yang digunakan adalah teknik analisis deskriptif kualitatif dan analisis deskriptif kuatitatif. Hasil penelitian yaitu hasil review ahli isi mata pelajaran mendapatkan kualifikasi sangat baik (100\%), hasil review ahli desain pembelajaran sangat baik (90\%), hasil review ahli media pembelajaran baik (86,7\%), hasil uji perorangan sangat baik (97,3\%), (e) hasil uji kelompok kecil sangat baik (95,7\%). Dapat disimpulkan bahwa e-modul interaktif berbasis inkuiri sangat valid dan layak digunakan dalam pembelajaran. implikasi penelitian ini yaitu media yang dikembangkan dapat digunakan oleh guru dalam membantu siswa belajar.

Kata kunci: E-Modul, Inquiry Learning

Abstrak

Currently, conventional teaching materials and learning media have not met the learning demands in the 4.0 evolutionary era. It results in many students who do not understand the subject matter, so that the learning objectives have not been achieved optimally. This study aims to produce an inquiry-based interactive electronic module to support learning. This type of research is development research using the ADDIE model, which includes the analysis, design, development, implementation, and evaluation stages. The techniques used in collecting data are observation, interviews, and questionnaires. The instrument used to collect data is a questionnaire. The analysis used is qualitative descriptive analysis technique and quantitative descriptive analysis. The research results review subject matter experts who get very good qualifications $(100 \%)$. The results of the learning design expert review are very good $(90 \%)$. The results of the learning media expert review are good $(86.7 \%)$. The individual test results are very good $(97,3 \%)$. The small group test results are very good $(95.7 \%)$. It can be concluded that the inquiry-based interactive e-module is very valid and feasible to use in learning. This research implies that teachers can use the developed media to help students learn.

Keywords: E-Module, Inquiry Learning

\begin{tabular}{|c|c|c|}
\hline History: & & Publisher: Undiksha Press \\
\hline Received & February 02,2021 & Licensed: This work is licensed under \\
\hline Revised & March 03, 2021 & a Creative Commons Attribution 3.0 License \\
\hline Accepted & March 25, 2021 & (c) (9) \\
\hline Published & April 25, 2021 & \\
\hline
\end{tabular}

\section{Introduction}

Today the world continues to experience changes towards a more sophisticated and modern. The demands of the industrial era 4.0 can only be met if graduates become human resources forged from an educational process that meets 4.0 education standards. Education 4.0 is characterized by more digital technology (cyber systems) in the learning process (Lase, 2019; Willya et al, 2019). With this technology, the learning process can occur without being limited by space and time, meaning that the learning process is not only in the classroom and during study hours (Muswita, et al 2018; Susmiati, 2020). So that information technology plays an important role in developing innovations. Today's problem is that many schools have not maximized today's information technology (Mawarni \& Muhtadi, 2017; Yusri, 2016). Based on observations made at SD Negeri 10 Pedungan, the implementation of the 
learning process is still carried out with the lecture method where learning is only teachercentered, not student-centered, so that teachers will dominate the learning process in the classroom. In contrast, students become passive because the teacher is only a source of learning. The teacher's role as a facilitator has not been seen in the learning process. Based on the interviews conducted with one of the fifth-grade teachers of SD Negeri 10 Pedungan, it was stated that teachers complained that it was difficult to teach material that contained simulations during this pandemic. In addition, teachers did not have enough time to develop teaching materials that could create a learning process. Independent in students and integrated with technology.

The teacher mentioned that very few media or interactive teaching materials were found for the human digestive system material. According to him, during the online learning process, students are required to learn independently. For that, it is necessary to have independent teaching materials to support the online learning process. In addition to the interviews with class teachers, the findings obtained in the field that the science learning outcomes achieved by fifth-grade students in the odd semester with 28 students still did not meet the specified Minimum Completeness Criteria, 70. It was found that the average pure science learning outcomes were fifth-grade students of SD Negeri 10 Pedungan are still not satisfactory, 65.32. In the content of science learning, especially in student learning outcomes, there is a gap, the finding of problems with students not understanding the material that has been given. It is caused by the lack of interactive teaching materials or learning media with structured materials such as teaching modules as student learning guides both at school and outside school that support implementing an optimal learning process. The results of interviews with classroom teachers stated that students were less creative in finding material for the human digestive system because they thought the material was difficult.

In addition, students are less active when participating in learning because the teacher only sends materials and assignments, although occasionally explains learning materials with the help of PowerPoint media or videos on youtube. In this pandemic period, teachers find it more difficult to explain the material. Besides that, there are still few learning media or interactive teaching materials. From observations at SD Negeri 10 Pedungan, all students already have laptops and smartphones with the Android operating system. Besides that, SD Negeri 10 Pedungan are equipped with LCD projectors, laptops, and internet access. So it becomes a supporting aspect to develop learning media that can help students in learning science. In addition, the application of interesting learning models will also increase student motivation in learning (Putri, Suwatra, \& Tegeh, 2018; Trisnadewi, Putra, \& Ardana, 2020; Umbara, Sujana, \& Negara, 2020).

One of the interesting learning models that teachers can use is the inquiry learning model. The application of the inquiry learning model is used in science subjects that have more characteristics than natural phenomena that students must solve through scientific methods such as observation and experimentation (Ari, Dantes, \& Tastra, 2013; Pratiwi, Suartama, \& Tegeh, 2016). Science is one of the subjects that require students to think creatively and innovatively (Lestari, Putra, \& Negara, 2018; Yuliati, 2017). In science education, it does not only consist of facts, concepts, and theories that can be memorized but also consists of active activities or processes using scientific thoughts and attitudes in studying natural phenomena that have not been explained (Khofiyah, Santoso, \& Akbar, 2019; Kurniawati, Sudana, \& Mahadewi, 2013). Thus, the demand to continuously update scientific knowledge becomes a necessity. Creative teaching material is needed that can help students learn to make it easier for students to understand science material (Diyantari, Wiyasa, \& Manuaba, 2020; Lubis \& Ikhsan, 2015).

Teaching materials are systematically arranged, both written and unwritten, to create an environment or atmosphere that allows students to learn (Asriani, Sa'dijah, \& Akbar, 
2017; Qondias, Winarta, \& Siswanto, 2019). Teaching materials need to be used during teaching and learning activities to improve the quality of education. For this reason, the development of existing teaching materials is very important for teachers so that learning is more effective and efficient. Teaching materials are various forms of materials used by a teacher to carry out the learning process (Sriyanto, Leksono, \& Harwanto, 2019; Syafii, 2017). Teaching materials also take many forms. According to Prastowo (2018) based on the form of teaching materials are grouped into four which include (1) printed teaching materials (printed), (2) hearing teaching materials (audio), (3) hearing teaching materials (audiovisual), (4) interactive teaching materials ).

One form of teaching material that can be used to assist the learning process is a module. A module is a book written to learn independently without or with teacher guidance (Fadillah \& Jamilah, 2016; Gafur, 2012). At this time, most of the modules are only made in the form of print modules. Printed modules tend to be less attractive and monotonous. The rapid development of information technology has enabled the development of learning in changing the presentation of teaching materials, in this case, the print module, into a module packaged in digital format or known as an electronic module (E-Module). (Diantari et al, 2018; Laili, Ganefri, \& Usmeldi, 2019). E-module is a module in an electronic version that can be accessed, and its use can be done through electronic devices such as computers, laptops, tablets, or smartphones. Text on the E-module can be created using Microsoft Word. But to display interactive media, E-modules must be created using special e-book programs such as Flipbook Maker, iBooks Author, Caliber, Lectora Inspire, and many more (Aryawan, Sudatha, \& Sukmana, 2018; Zainul et al, 2018). The advantages of E-modules from other printed teaching materials are that they are complete with interactive media such as video, audio, animation, and other interactive features that can be played and replayed by students when using E-modules (Pramana, Jampel, \& Pudjawan, 2020; Udayana, Wirawan, \& Divayana, 2017).

E-modules are considered innovative because they can display teaching materials that are complete, interesting, interactive, and carry good cognitive functions. A module is a unit of planned learning activities designed to help students complete certain goals by organizing subject matter tailored to the individual's personality to maximize his intellectual abilities (Kimianti \& Prasetyo, 2019; Suhaida \& Fadillah, 2019). Previous research on E-modules states that E-modules are effectively used as teaching materials and can improve student learning outcomes (Darmayasa, Jampel, Simamora, \& Pendidikan, 2018; Winaya, Darmawiguna, \& Sindu, 2016). Based on the explanation above, there is no study on inquirybased interactive E-modules that can help students learn. This study aims to produce an inquiry-based interactive electronic module to support learning. It is hoped that the development of inquiry-based interactive E-modules can help students learn to improve science learning outcomes for elementary school students.

\section{Methods}

This type of research is included in development research. Development research is a method used to produce a certain product. The resulting product can be teaching materials or learning media, test instruments, and others. This study developed an interactive e-module based on the human digestive system material inquiry on healthy food in fifth-grade elementary school. The research model used is the ADDIE model, which consists of Analysis, Design, Development, Implementation, and Evaluation. The techniques used in data collection are observation, interviews, and questionnaires or questionnaires. The observation technique was used to determine the online learning process carried out by fifthgrade teachers at SD Negeri 10 Pedungan. Interview technique to obtain factual information directly. The interview method was conducted with fifth-grade teachers at SD Negeri 10 
Pedungan. During the subject matter expert test, questionnaires were given, learning design expert test, learning media expert test, and product trial to fifth-grade students at SD Negeri 10 Pedungan. The instrument used to collect data is a questionnaire. The data analysis method used in this research is descriptive analysis method and statistical analysis method. This qualitative descriptive analysis technique is used to process data from the review of content experts in study or subjects, learning design experts, learning media experts, students, and subject teachers. The validity of this inquiry-based interactive e-module was measured by conducting expert tests and product trials which included subject content expert tests, learning design expert tests, learning media expert tests, and individual trials. The determination of the Level of Achievement Conversion Scale is used to give meaning and make decisions on the results of the questionnaire or questionnaire.

\section{Results and Discussion}

The preparation for the development of an inquiry-based interactive e-module has been carried out following the development procedure. Developing an inquiry-based interactive e-module was developed using the ADDIE model, which is as follows. The first stage is the analysis. At this stage of analysis, it is carried out so that the resulting product can be useful for schools in carrying out learning. At this stage, an analysis of the problems experienced by the school related to the learning media commonly used in the implementation of learning is carried out. In addition, it is also analyzed about learning materials that are difficult for students to understand. In this analysis phase, an analysis of student needs was carried out to determine the needs needed by students. Through interviews with the fifth-grade guardian of SD Negeri 10 Pedungan, it was found that during a pandemic like now, teaching and learning activities are becoming more difficult due to the limitations of teaching and learning facilities' support and limitations. -Other limitations that hinder the learning process. In addition, students find it more difficult to understand the material, especially materials that require simulation, such as science subjects for the human digestive system.

After analyzing student needs, content analysis is carried out. Content analysis is carried out to find out the right subject matter to be used in the product. Based on the fifthgrade homeroom teacher interviews, the material used in inquiry-based interactive e-module products is material for the human digestive system. After knowing the right material, the next step is to identify core competencies, basic competencies, and indicators in science subjects for the human digestive system. After doing the two analyses, the last analysis is carried out, analyzing the school environment. The school environment analysis was carried out by observing the research subject schools, SD Negeri 10 Pedungan. Based on observations, SD Negeri 10 Pedungan already has learning support facilities such as laptops, LCD projectors, $\mathrm{WiFi}$, and the guardians of all students have cellphones. In this way, an inquiry-based interactive e-module is suitable to be developed at SD Negeri 10 Pedungan.

The second stage is designing. An outline of the media content is developed (learning materials, learning objectives, basic competencies, indicators, and evaluations). Media development uses the Articulate Storyline application to create interactive e-modules. Next, determine the display (storyboard) and flowchart of the interactive e-module, including the design of the cover display, typeface, font size, spacing, and coloring in the interactive emodule application before further development. The third stage is development. The development stage includes pre-production, production, and post-production. The stage of producing interactive E-modules begins with determining learning materials that suit the needs of students. The software used in producing this interactive E-module is Articulate Storyline. In this development stage, before being applied directly in learning, first, check 
and validate the material experts to assess whether the content is following the learning indicators and media experts to assess the feasibility of the interactive E-module media.

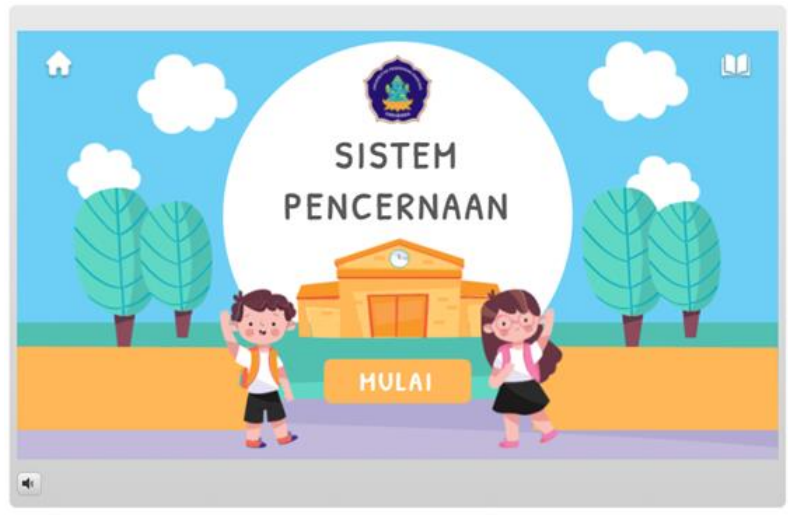

Figure 1. Initial view of the E-Module

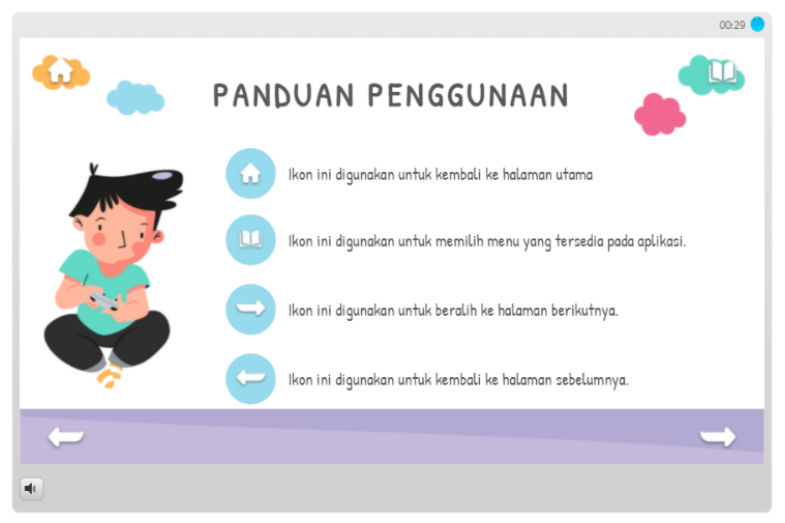

Figure 2. User Guide Display

The fourth stage is implementation. After the product has been made and is declared feasible, the next stage is implementing the Interactive E-module media in the learning process. This implementation was carried out at SD Negeri 10 Pedungan, precisely in the fifth grade of elementary school. This implementation is carried out to determine the user's response to the media for the learning process. Things that need to be done at this stage are: (1) Product validation is carried out by experts, including science learning content experts, learning media experts, and learning design experts. And (2) Product trials are carried out, both individual trials. The last stage is evaluation. This evaluation stage is carried out after the data at the implementation stage is collected. The evaluation carried out is in the form of formative evaluation. Formative evaluation is carried out to measure or assess learning products which include expert validation, individual trials, small group trials, and field trials.

Table 1. Product Validity Test Results

\begin{tabular}{cccc}
\hline No. & E-Module Trial Subject & Validity Results (\%) & Description \\
\hline 1. & Subject Content Expert Test & $100 \%$ & Very good \\
2. & Learning Design Expert Test & $90 \%$ & Very good \\
3. & Learning Media Expert Test & $87 \%$ & Good \\
4. & Individual Trial & $97 \%$ & Very good \\
\hline
\end{tabular}

Based on Table 1, the results of the Inquiry-Based Interactive E-Module Product Validity Test, the content expert test results were $100 \%$ based on the Achievement Level Conversion table with a scale of 5 subject content expert validity in the very good category. Furthermore, the design expert test results obtained results of $90 \%$, namely in the very good category. Based on the corrections from the learning media experts, the results were $87 \%$, with a good category where this good category needed a little revision to perfect the inquirybased interactive e-module product. After conducting the subject content expert test, the learning design expert test, and the learning media expert test, the product trial was carried out to the fifth-grade students of SD Negeri 10 Pedungan. Based on these inputs, the developed media was revised again to produce appropriate and quality learning media. Next, the product is tested. The trial results of this product development will be presented with five main points, the Learning Content Expert Test, Learning Design Expert Test, Learning Media Expert Test, Individual Trial, and Small Group Trial. The five data will be presented successively following the results obtained from each stage of the trial. Based on the 
assessment results from individual trials, after being converted to a conversion table, the percentage of the achievement level of $97.33 \%$ is in the very good predicate. Based on the assessment results, after being converted to a conversion table, the percentage of the achievement level of $95.41 \%$ is in the very good predicate. It can be concluded that the inquiry-based interactive e-module is appropriate to be used to assist teachers in explaining the science material of the human digestive system on the theme of 3 healthy foods for fifth grade at SD Negeri 10 Pedungan. It is caused by several factors, as follows.

First, inquiry-based interactive e-modules are appropriate because they can increase students' enthusiasm for learning. The elementary school-age period has high enthusiasm and curiosity to learn new things (Lieung, 2019; Ulia \& Sari, 2018). When students use the inquiry-based interactive E-module that has been developed, students' curiosity increases. In addition, students also feel the spirit of independent learning. This science learning electronic module (E-Modul) teaching material integrates character education in every aspect of learning by inserting character education values for fifth-grade elementary school students. So that through electronic module teaching materials (E-Modules), students are more motivated to learn, love to read, work hard, be honest, independent, diligent, communicative, and disciplined following the guidance of good character for students. It can be concluded that a proper E-module can increase student motivation in learning (Aryawan et al., 2018; Darmayasa et al., 2018).

Second, inquiry-based interactive E-modules are appropriate because they can make it easier for students to understand the subject matter presented in the E-modules. The material presented in the material inquiry-based interactive E-module can spur students to think critically and stimulate students' curiosity about the material. The use of innovative teaching materials makes learning not monotonous, boring and has a good impact on the learning process, which results in a more optimal learning process (Sriyanto et al., 2019; Syafii, 2017). The learning process will not become effective if there are no supporting teaching materials (Fadillah \& Jamilah, 2016; Qondias et al., 2019). Inquiry-based interactive e-modules present material appropriate for science learning with grammar following student characteristics, making it easier for students to understand the subject matter. Using this E-module, students will be faster to catch the material explained. The module must describe the Basic Competencies that students will achieve and be presented using good, interesting language and equipped with illustrations.

Previous research stated that E-modules could make it easier for students to understand the subject matter (Laili et al., 2019). Other research also states that E-modules can increase students' enthusiasm and interest in learning to improve student learning outcomes (Darmayasa et al., 2018; Pramana et al., 2020; Sugihartini \& Laba, 2017). So it can be concluded that the E-module can help students learn so that learning objectives can be achieved optimally. This research implies that teachers can use the developed E-module in helping students learn independently so that learning objectives can be achieved optimally. In addition, the developed E-modules can also be used as guidelines for developing other Emodules.

\section{Conclusion}

Based on the results of data analysis, the assessments carried out by subject content experts, learning media experts, learning media experts, and testing the developed media products obtained very good qualifications. It can be concluded that the inquiry-based interactive e-module is appropriate to be used to assist teachers in explaining the science material of the human digestive system on the theme of 3 healthy foods for fifth grade at SD Negeri 10 Pedungan. 


\section{References}

Ari, N., Dantes, N., \& Tastra, I. D. K. (2013). Pengaruh Model Pembelajaran Inkuiri Terbimbing Berbantuan Peta Konsep terhadap Hasil Belajar IPA Kelas V. MIMBAR PGSD Undiksha, 1(1).

Aryawan, Sudatha, \& Sukmana. (2018). Pengembangan E-Modul Interaktif Mata Pelajaran IPS Di Smp Negeri 1 Singaraja. Jurnal Edutech Undiksha, 6(2), 180-191. https://doi.org/http://dx.doi.org/10.23887/jeu.v6i2.20290.

Asriani, P., Sa'dijah, C., \& Akbar, S. (2017). Bahan Ajar Berbasis Pendidikan Karakter Untuk. Jurnal Pendidikan: Teori, Penelitian, Dan Pengembangan, 2(11), 1456-1468. https://doi.org/http://dx.doi.org/10.17977/jptpp.v2i11.10160.

Darmayasa, I. K., Jampel, N., Simamora, A. H., \& Pendidikan, J. T. (2018). Pengembangan E-Modul Ipa Berorientasi Pendidikan Karakter Di Smp Negeri 1 Singaraja. Jurnal Edutech Undiksha, 6(1), 53-65. https://doi.org/http://dx.doi.org/10.23887/jeu.v6i1.20267.

Diantari, Damayanthi, Sugihartini, \& Wirawan. (2018). Pengembangan E-modul berbasis Mastery Learning untuk Mata Pelajaran KKPI Kelas XI. Jurnal Nasional Pendidikan Teknik Informatika (Janapati), 3(1), 33-48. https://doi.org/http://dx.doi.org/10.23887/janapati.v7i1.12166.

Diyantari, I. A. K. D., Wiyasa, N., \& Manuaba, S. (2020). Model Snowball Throwing Berbantuan Media Pop Up Book Berpengaruh Terhadap Kompetensi Pengetahuan Ipa. Jurnal Ilmiah Pendidikan Profesi Guru, 3(1), 9-21. https://doi.org/http://dx.doi.org/10.23887/jippg.v3i1.26973.

Fadillah, \& Jamilah. (2016). Pengembangan Bahan Ajar Struktur Aljabar Untuk Meningkatkan Kemampuan Pembuktian Matematis Mahasiswa. Cakrawala Pendidikan, 35(1), 106-108. https://doi.org/https://doi.org/10.21831/cp.v1i1.8379.

Gafur, A. (2012). Desain Pembelajaran Konsep, Model, dan Aplikasinya dalam Perencanaan Pelaksanaan Pembelajaran. Yogyakarta: Penerbit Ombak.

Khofiyah, H. N., Santoso, A., \& Akbar, S. (2019). Pengaruh Model Discovery Learning Berbantuan Media Benda Nyata terhadap Kemampuan Berpikir Kritis dan Pemahaman Konsep IPA. Jurnal Pendidikan: Teori, Penelitian, Dan Pengembangan, 4(1), 61-67. https://doi.org/http://dx.doi.org/10.17977/jptpp.v4i1.11857.

Kimianti, \& Prasetyo. (2019). Pengembangn E-aModul Ipa Berbasis Problem Based Learning Untuk Meningkatkan Literasi Sains Siswa. Kwangsan Jurnal Teknologi Pendidikan, 7(2), 91-103. https://doi.org/http://doi.org/10.31800/jtp.kw.v7n2.p91--103.

Kurniawati, N. M. E., Sudana, D. N., \& Mahadewi, L. P. P. (2013). Pengaruh Model Pembelajaran Reciprocal Teaching Terhadap Penguasaan Konsep Ipa Siswa Kelas V Sd Gugus I Kecamatan Buleleng. Mimbar PGSD Undiksha, 1(1). https://doi.org/http://dx.doi.org/10.23887/jjpgsd.v1i1.1358.

Laili, Ganefri, \& Usmeldi. (2019). Efektivitas Pengembangan E-Modul Project Based Learning pada Mata Pelajaran Instalasi Motor Listrik. Jurnal Ilmiah Pendidikan Dan Pembelajaran, 3(3). https://doi.org/http://dx.doi.org/10.23887/jipp.v3i3.21840. 306309.

Lase, D. (2019). Pendidikan di Era Revolusi Industri 4.0. Jurnal Sundermaan, 1(1). https://doi.org/https://doi.org/10.36588/sundermann.v1i1.18.

Lestari, K. P., Putra, D. K. N. S., \& Negara, I. G. A. O. (2018). Pengaruh Model Discovery Learning Berbantuan Media Audio Visual dalam Setting Lesson Study Terhadap Hasil Belajar IPA Mahasiswa PGSD Undiksha UPP Denpasar Tahun 2017. Jurnal Ilmiah Sekolah Dasar, 2(1), 40-45. https://doi.org/http://dx.doi.org/10.23887/jisd.v2i1.13898.

Lieung, W. K. (2019). Pengaruh Model Discovery Learning terhadap Keterampilan Berpikir 
Kritis Siswa Sekolah Dasar. Musamus Journal of Primary Education, 1(2), 73-82. https://doi.org/https://doi.org/10.35724/musjpe.v1i2.1465.

Lubis, \& Ikhsan. (2015). Pengembangan Media Pembelajaran Kimia Berbasis Android Untuk Meningkatkan Motivasi Belajar Dan Prestasi Kognitif Peserta Didik SMA. Jurnal Inovasi Pendidikan IPA, 1(2). https://doi.org/https://doi.org/10.21831/jipi.v1i2.7504.

Mawarni, \& Muhtadi. (2017). Pengembangan Buku Digital Interaktif Mata kuliah Pengembangan Multimedia Pembelajaran Interaktif Untuk Mahasiswa Teknologi Pendidikan. Jurnal Inovasi Teknologi Pendidikan, 4(1). https://doi.org/https://doi.org/10.21831/jitp.v4i1.10114.

Muswita, Utomo, A. B., Yelianti, U., \& Wicaksana, E. J. (2018). Pengembangan E-Book Berbasis Mobile Learning Pada Mata Kuliah Struktur Tumbuhan. Pendidikan Biologi, 11, 93-104. https://doi.org/https://doi.org/10.20961/bioedukasi-uns.v11i2.23814.

Pramana, Jampel, \& Pudjawan. (2020). Meningkatkan Hasil Belajar Biologi Melalui EModul Berbasis Problem Based Learning. Jurnal Edutech Undiksha, 8(2), 18-32. https://doi.org/http://dx.doi.org/10.23887/jeu.v8i2.28921.

Prastowo, A. (2014). Panduan Kreatif Membuat Bahan Ajar Inovatif. Yogyakarta: Diva Press.

Pratiwi, I., Suartama, I. K., \& Tegeh, I. M. (2016). Pengembangan E-Learning dengan Model Prototype Berorientasi Model Pembelajaran Inquiry Siswa Kelas VII SMPN 2 Negara. Jurnal Edutech Undiksha, 4, No 2. https://doi.org/http://dx.doi.org/10.23887/jeu.v4i2.7615.

Putri, Suwatra, \& Tegeh. (2018). Pengaruh Model Pembelajaran PBL Berbantuan Media Gambar Terhadap Hasil Belajar IPA Siswa Kelas III SD. Jurnal Mimbar Ilmu, 23(1), 53-64. https://doi.org/http://dx.doi.org/10.23887/mi.v23i1.16407.

Qondias, D., Winarta, \& Siswanto. (2019). Pengembangan Bahan Ajar Berbasis Pendekatan Saintifik pada Mata Kuliah Metodologi Penelitian. Jurnal Penelitian Dan Pengembangan Pendidikan, $\quad 3(2), \quad 145-148$. https://doi.org/doi.org/10.23887/jppp.v3i2.17393.

Sriyanto, Leksono, \& Harwanto. (2019). Bahan Ajar PPKn Berbasis Karakter dan Literasi Untuk Siswa Kelas IX SMP Al Hikmah Surabaya. Edmotech, 4(2), 130-142. https://doi.org/http://dx.doi.org/10.17977/um039v4i22019p130.

Sugihartini, \& Laba. (2017). Pengembangan E-modul mata kuliah strategi pembelajaran. Jurnal Pendidikan Teknologi Dan Kejuruan, 14(2), 221-230.

Suhaida, D., \& Fadillah, S. (2019). Media Kajian Kewarganegaraan membentuk karakter siswa. Jurnal Civics: Media Kajian Kewarganegaraan, 16(2), 111-121. https://doi.org/https://doi.org/10.21831/jc.v16i2.21757.

Susmiati, E. (2020). Meningkatkan Motivasi Belajar Bahasa Indonesia Melalui Penerapan Model Discovery Learning dan Media Video Dalam Kondisi Pandemi Covide-19 bagi Siswa SMPN 2 Gangga. Jurnal Penelitian Dan Pengembangan Pendidikan, 7(3). https://doi.org/https://doi.org/10.33394/jp.v7i3.2732.

Syafii. (2017). Pengembangan Bahan Ajar Ornamen Berbasis Candi di Jawa Tengah: Studi Identifikasi Candi Gedongsanga. Imajinasi Jurnal Seni, 11(2), 117-124. https://doi.org/https://doi.org/10.15294/imajinasi.v11i2.12813.

Trisnadewi, N. K., Putra, M., \& Ardana, I. K. (2020). Model Advance Organizer Berbantuan Media Grafis Berpengaruh Terhadap Kompetensi Pengetahuan IPS. Mimbar Ilmu Undiksha, 25(2), 1-12. https://doi.org/http://dx.doi.org/10.23887/mi.v25i2.25152.

Udayana, Wirawan, \& Divayana. (2017). Pengembangan E-modul pada mata pelajaran pemrograman berorientasi objek dengan model pembelajaran Problem Based Learning Kelas VIII rekayasa perangkat lunak. Jurnal Nasional Pendidikan Teknik Informatika

(Janapati),

$6(2)$,

128-139. 
https://doi.org/http://dx.doi.org/10.23887/janapati.v6i2.9373.

Ulia, N., \& Sari, Y. (2018). Pembelajaran Visual, Auditory dan Kinestetik Terhadap Keaktifan dan Pemahaman Konsep Matematika Siswa Sekolah Dasar. Al Ibtida: Jurnal Pendidikan Guru https://doi.org/https://doi.org/10.24235/al.ibtida.snj.v5i2.2890.

Umbara, I. A. A. P., Sujana, I. W., \& Negara, I. G. A. O. (2020). Model Pembelajaran Problem Based Learning Berbantuan Media Gambar Seri BerpengaruhTerhadap Kompetensi Pengetahuan IPS Siswa. Jurnal Mimbar Ilmu, 25(2), 174-186. https://doi.org/http://dx.doi.org/10.23887/mi.v25i2.25154.

Willya, Poluakan, Dikayuana, Wibowo, \& Raharjo. (2019). Generasi Milenial Pada Era Revolusi Industri 4.0. Focus: Jurnal Pekerjaan Sosial, 2(2). https://doi.org/https://doi.org/10.24198/focus.v2i2.26241.

Winaya, I., Darmawiguna, I., \& Sindu, I. (2016). Pengembangan E-Modul Berbasis Project Based Learning pada Mata Pelajaran Pemrograman Web Kelas X di SMK Negeri 3 Singaraja. Jurnal Pendidikan Teknologi Dan Kejuruan, 13(2).

Yuliati, Y. (2017). Literasi sains dalam pembelajaran IPA. Jurnal Cakrawala Pendas, 3(2). https://doi.org/http://dx.doi.org/10.31949/jcp.v3i2.592.

Yusri. (2016). Pengaruh Penggunaan Media Teknologi Informasi dan Komunikasi (TIK) dengan Prestasi Belajar Bahasa Inggris Peserta Didik Kelas X di SMAN I Dekai Kabupaten Yahukimo. Ilkom Jurnal Ilmiah, 8(1), 49-56. https://doi.org/https://doi.org/10.33096/ilkom.v8i1.22.49-56.

Zainul, R., Oktavia, B., Guspatni, \& Putra, A. (2018). Pengenalan Dan Pengembangan EModul Bagi Guru- Guru Anggota MGMP Kimia Dan Biologi Kota Padang Panjang. https://doi.org/https://doi.org/10.31227/osf.io/yhau2. 